\title{
INFESTASI KUTU PADA AYAM KAMPUNG (Gallus gallus domestic) DI DESA TOLOK KECAMATAN TOMPASO KABUPATEN MINAHASA
}

\author{
Hartina S. Balaira, G.J.V. Assa, F.J. Nangoy, C.L.K. Sarajar, Meis Nangoy*
}

Fakultas Peternakan, Universitas Sam Ratulangi Manado, 95115

\begin{abstract}
ABSTRAK
Penelitian bertujuan menghitung infestasi jenis kutu, mengetahui tingkat kesukaan (preferensi) infestasi kutu pada bagian tubuh dan berdasarkan jenis kelamin. Metode purposive random sampling, digunakan dalam pengambilan sampel yang dilakukan secara manual pada tubuh ternak pada pagi dan sore hari dengan cara penyisiran seluruh bagian tubuh secara berurutan mulai dari kepala, leher, punggung, abdomen, paha dan ekordengan menggunakan rabaan jari tangan dan pengambilan dengan pinset, sampel yang sudah ditemukan di simpan dalam botol yang berisi alkohol $70 \%$. untuk dilakukan penghitungan dan identifikasi kutu. Hasil penelitian menunjukkan jenis kutu yang ditemukan hanya satu jenis kutu yaitu Menopon gallinae dengan prevalensi infestasi kutu yang ada 87,5\% dari 40 ekor ayam kampung dan preferensi infestasi berdasarkan bagian tubuh menunjukkan pada bagian punggung merupakan daerah terbanyak dengan rataan 6,23 ekor/ayam dibadingkan dengan leher 3,43ekor/ayam, abdomen 5,48 ekor/ayam, paha 0,83 ekor/ayam dan ekor 1,28 ekor/ayam. Sedangkan tingkat kesukaan (preferensi) berdasarkan jenis kelamin ternak betina merupakan ternak terbanyak dengan rataan
\end{abstract}

*Korespondensi (corresponding aouthor) Email: mjnangoy@yahoo.com (20,35ekor/ ayam) sedangkan jantan $(14,10$ ekor/ayam).

Kata kunci: Infestasi, Kutu, ayam kampung

ABSTRACT
LOUSE INFESTATION AT
LOCAL LAYING HENS (Gallus gallus
domestic) AT TOLOKVILLAGE
TOMPASO OF
MINAHASA REGENCY. The objective
of this study was to count the infestation,
preference of this louse on parts of the body
and sex of birds, The purposive random
sampling method was used in sample
collection implemented manually on the
birds stated in the morning and in the
afternoon by screening all body of birds
initiated from head, neck, hip, abdomen,
thigh, and tail using all fingers. Samples of
louses found were filled into bottle
containing alcohol of $70 \%$. Samples of
louses were counted. Result showed that the
parasite found one type of louse (Menopon
gallinae) with preference infestation of
$87.5 \%$ from 40 local laying hens spreading
on the body parts of birds in the average
frequencies on hip of birds about 6.23
louses/bird, on neck of bird about 3.43
louse/bird, on abdomen of bird about 5.48
louses/bird, on thigh about 0.83 louses/bird
and on tail about 1.28 louses/bird. The
preference of parasite was found on female
bird with the average of 20.35
louses/female bird and 14.10 louse/male
bird.


Key words: Infestation, louses, local laying hens.

\section{PENDAHULUAN}

Ayam kampung merupakan ayam lokal Indonesia yang sangat dekat dengan kehidupan masyarakat. Penyebaran ayam kampung hampir terdapat diseluruh wilayah Indonesia dan dapat dijumpai di daerah pedesaan maupun perkotaan. Ayam kampung mempunyai peranan penting dalam kehidupan manusia yaitu sebagai sumber protein hewani untuk memenuhi kebutuhan sehari-hari. Umumnya, dalam pemeliharaan ayam kampung di Indonesia peternak masih menggunakan sistem pemeliharan tradisional dengan cara diumbar, ayam kampung biasanya hidup didataran rendah dengan ketinggian 500$800 \mathrm{~m}$ dari pemukaan laut (Mansjoer, 1985; Getu dan Birha, 2014).

Desa Tolok merupakan desa yang berada di Kecamatan Tompaso Kabupaten Minahasa Provinsi Sulawesi Utara. Kecamatan Tompaso terdiri dari 10 desa yang termasuk di dalamnya Desa Tolok sedangkan untuk luas wilayah dalam satu kecamatan yaitu $17,32 \mathrm{Km}^{2}$ dengan jumlah penduduk 7.584 dan populasi ternak ayam kampung mencapai 13.231 ternak, jadi ratarata ternak dalam satu desa diperkirakan mencapai 1.323 ekor ternak ayam kampung
(BPS Kabupaten Minahasa 2018). Peternakan rakyat di desa Tolok banyak memelihara ayam kampung untuk memenuhi kebutuhan hidup sehari-hari baik untuk hari raya keagamaan, pesta pernikahan, maupun sebagai tabungan dan lain-lain. Sistem pemeliharan ayam kampung umumnya kandang yang terbuat dari bambu dan kayu, pemberian pakan sebanyak satu kali dengan pakan jagung atau sisa-sia makan. Selain itu sistem pemeliharan yang masih tradisional menyebabkan ayam kampung terserang penyakit salah satunya oleh kutu. Kutu merupakan serangga ektoparasit obligat karena seluruh hidupnya tergantung pada tubuh inang. Kutu yang menginfestasi ternak ayam kampung dapat menyebabkan kerugian baik untuk ternak ayam maupun peternak.

Cara penanganan kutu yang dilakukan di desa Tolok umumnya masih tradisional dengan menggunakan bahan alami yang berasal dari tumbuhan yang ada di sekitar pemukiman masyarakat. Bahan yang digunakan yaitu daun sirsak yang dihaluskan untuk mengusir kutu baik pada area tubuh atau tempat ayam mengeram ayam cara tersebut termasuk cukup efektif untuk mengatasi yang menginfestasi kutu pada ayam kampung. Berdasarkan uraian tersebut diperlukan penelitian mengenai infestasi jenis kutu pada ayam kampung yang ada di Desa Tolok Kecamatan 
Tompaso Kabupaten Minahasa. Infestasi kutu yang tinggi dapat menyebabkan kematian pada ternak ayam, kurangnya penelitian mengenai infestasi kutu membuat kurangnya informasi mengenai jenis kutu yang menginfestasi ayam serta dampak infestasi kutu terhadap ternak maupun peternak.

Dari penelitian ini diharapkan dapat tersedianya data ilmiah mengenai jenisjenis kutu serta menjadi bahan penyuluhan kepada masyarakat tentang kesehatan ternak dan pegaruh kutu terhadap ternak ayam yang mengakibatkan kerugian baik untuk ternak maupun peternak.

\section{MATERI DAN METODE PENELITIAN}

\section{Tempat dan Waktu Penelitian}

Penelitian ini dilakukan di Desa Tolok Kecamatan Tompaso Kabupaten Minahasa selama 2 bulan mulai dari bulan september- oktober.

\section{Ternak}

Ternak yang digunakan pada penelitian ini berjumlah 40 ekor milik dari petani dan peternak di desa Tolok

\section{Metode Penelitian}

Penelitian menggunakan metode purposive random sampling, pengambilan sampel dilakukan secara manual pada tubuh ternak pagi dan sore hari dengan cara penyisiran seluruh bagian secara beruruta mulai dari, leher, punggung, abdomen, paha dan ekor menggunakan rabaan jari tangan dan pengambilan dengan pinset (Hopla, 1994).

Kutu yang tertangkap dimasukkan dalam botol sampel yang sudah berikan label sesuai dengan nomor ternak, bagian tubuh, dan tanggal pengambilan sampel, kemudian diberi alkohol 70\% (Zein and Saim 2001). Sampel yang sudah diperoleh dibawa ke Laboraturium Satwa Liar dan Endemik Fakultas Peternakan Universitas Sam Ratulangi Manado, untuk dilakukan penghitungan dan identifikasi dibawah digital mikroskop dengan perbesaran 1600 (kali) untuk diamati ciri morfologinya menggunakan buku panduan Hadi dan Soviana (2013), hasil yang diperoleh dihitung dan dianalisis secara deskriptif dan di dokumentasikan dalam bentuk foto.

\section{Variabel penelitian}

1. Menentukan jenis-jenis kutu yang menginfestasi ternak ayam kampung di Desa Tolok

2. Menghitung prevalensi infestasi kutu pada ayam kampung yang ada di Desa Tolok

3. Preferensi infestasi berdasarkan bagian tubuh ternak ayam dengan cara menghitungjumlah kutu dan rata-rata di setiap bagian tubuh ternak ayam. 
4. Preferensi infestasi berdasarkan jenis kelamin dengan cara menghitung ratarata kutu pada setiap jenis kelamin baik jantan dan betina.

\section{Analisa Data}

Prevalensi yaitu jumlah keseluruhan kasus yang terjadi pada waktu tertentu di suatu wilayah tertentu (Armaidi, 2016; Timmereck, 2001). Untuk menghitung prevalensi infestasi kutu pada ayam kampung yang ada di desa Tolok dengan menggunakan rumus dari Husna (2014):

$$
\text { Prevalensi }=\frac{(\mathrm{X})}{(\mathrm{N})} \times 100 \%
$$

Keteragan :

$(\mathrm{X})=\underset{\text { jumlah ayam kampung yang }}{\text { terinfestasi }}$ $(\mathrm{N})=$ jumlah ayam kampung yang diamati Untuk Preferensi infestasi kutu dihitung menggunakan microsoft office excel (2010) dengan menghitung rata-rata kutu yang terdapat pada bagian tubuh baik jantan maupun betina

\section{HASIL DAN PEMBAHASAN}

\section{Jenis Kutu}

Hasil penelitian didapatkan dari 40 ekor ayam kampung 35 positif terinfestasi kutusedangkan 5 ekor lainya tidak terinfestasi kutu, jenis kutu yang ditemukan pada penelitian ini hanya satu jenis yaitu Menopon gallinae termasuk ordo
Mallophaga merupakan kutu penggigit yang menginfestasi kutu pada ayam kampung di desa Tolok. Hasil penelitian ini sejalan dengan Selfiannisa (2018) pada ayam buras di desa Kramat Kabupatean Bangkalan juga ditemukan kutu Menopon gallinae pada areah tubuh. Pada pemeriksaan sampel yang dilakukan hasil identifikasi menunjukkan kutu Menopon gallinae mempunyai badan kecil, warna kuning kepucatan sampai dengan kuning kekuning-kuningan dengan bentuk kepala segi tiga yang lebar dengan ujung arterior tumpul, mempunyai mata majemuk, mempunyai antena dan pada bagian kaki mempunyai rambut yang berwarna coklat (Hadi dan soviana, 2013). Hasil penelitian dapat dilihat pada gambar 1

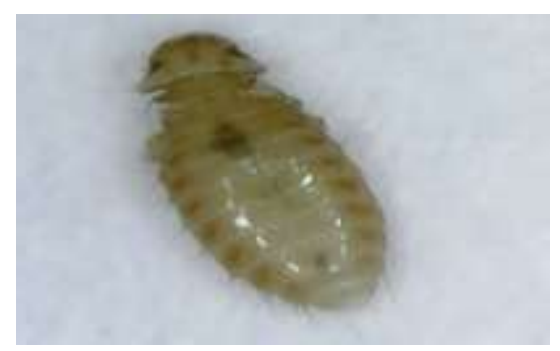

Gambar 1. Kutu Menopon gallinae

\section{Prevalensi Infestasi Kutu Pada Ayam Kampung}

Hasil penelitian menunjukkan pevalensi infestasi kutu pada ayam kampung di Desa Tolok sebesar 87,5 \% dari 40 ekor ayam kampung. Hasil pengamatan lokasi peternakan yang ada di Desa Tolok umumnya peternakan tradisional dengan kandang terbuat dari bambu dan kayu 
dengan jarak tidak jauh dari rumah, salah satu faktor yang mempengaruhi yaitu lingkungan kandang yang kurang bersih menurut Baktiar et al (2014) kondisi kandang yang kotor serta sanitasi yang kurang baik membuat kutu dapat berkembang bengan baik. Terlihat pada gambar 2 kondisi kandang pada lokasi penelitian terlihat kotor terdapat banyak sampah yang berserakan dibawah kandang, feses yang tidak dibersikan membuat parasit dapat berkembang dengan baik.

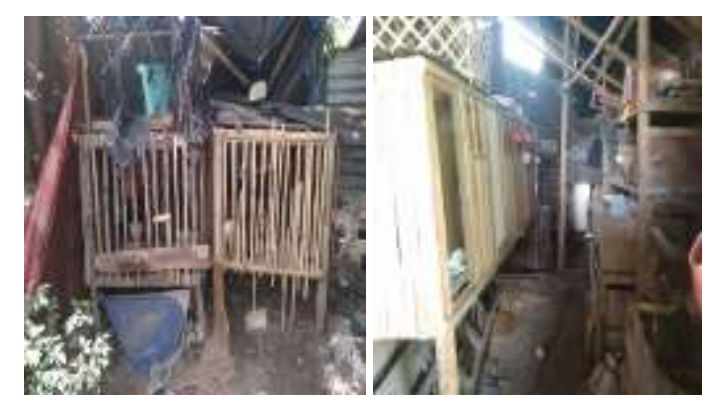

Gambar 2. Kondisi kandang

Hasil penelitian ini tidak berbeda dari hasil penelitian sudah dilakukan di Kabupaten Lampung Selatan oleh Hasnah (2017) menyatakan bahwa ektoparasit kutu pada ayam petelur (Gallus gallus) sebesar $50 \%$ dari 100 ekor ayam petelur yang terinfestasi kutu, begitu juga dengan studi kasus infestasi ektoparsit Desa Mulyoagung Kabupaten Malang oleh Febrananti (2014) prevalensi infestasi $100 \%$ dari 20 ekor ayam (kampung dan arab) terinfestasi kutu sedangkan hasil penelitian di Ethiopia oleh
Tamiru et al. (2014) menyatakan jumlah ayam yang terserang ektoparsit kutu 67,95\% dari 390 ekor ayam, di Meerut $70,73 \%$ dari 82 ekor ayam (Kansil dan Singh, 2014), sedangkan di Yobe yang terletak di Nigeria 84,50 \% ayam kampung terserang ektoparsit kutu dari 400 ekor ayam (Lawal et al. 2017). Menunjukkan setiap tempat memiliki tingkat prevalensi infestasi yang berbeda, ini berhubungan dengan jenis unggas, kondisi lingkungan, pola pemeliharaan dan faktor musim pada setiap tempat yang berbeda.

\section{Preferensi Infestasi Kutu Menopon gallinae Berdasarkan Bagian Tubuh}

Hasil penelitian tentang preferensi infestasi kutu berdasarkan bagian tubuh disajikan pada Tabel 1. data menunjukkan bagian tubuh ternak ayam kampung terinfesktasi kutu, pada bagian leher, punggung, abdomen paha dan ekor, insfetasi yang paling banyak di terdapat pada bagian punggung dengan rata-rata 6,23 ekor dan terkecil pada bagian paha 0,83 ekor. Hasil penelitian menunjukkan tidak disemua bagian tubuh ayam kampung terintestasi kutu hanya pada bagian punggung, abdomen, paha dan ekor. Infestasi kutu yang tinggi pada bagian punggung dikarenakan terdapat banyak Infestasi kutu yang tinggi pada 
Tabel 1. Rata-rata Preferensi Insfstasi Kutu Menopon gallinae Berdasarkan Bagian Tubuh Ayam Kampung

\begin{tabular}{llllll}
\hline Bagian tubuh $(\mathrm{N}=40)$ & Leher & Punggung & Abdomen & Paha & Ekor \\
\hline Rataan & $3,43 \pm 2,43$ & $6,23 \pm 3,392$ & $5,48 \pm 3,08$ & $0,83 \pm 1,71$ & $1,28 \pm 1,85$ \\
\hline
\end{tabular}

bagian punggung dikarenakan terdapat banyak bulu Plumae yang rapat, pada bagian ini kutu akan memakan batang, serabut bulu, bulu halus, kulit yang terlepas dan darah (Noble dan Noble, 1989) sedangkan pada bagian paha infestasi kutu terkecil karena jumlah bulu tidak serapat pada bagian punggung dan pada bagian ini kutu tidak dapat bersembunyi dari predator dengan cara mematuk. Salah satu faktor yang berpengaruh terhadap penyebaran kutu yaitu suhu tubuh inang, kondisi lingkungan, struktur bulu, morfologi kutu dan jumlah bulu pada inang (Marshall,1988). Kutu dengan rata-rata 200-500 ekor akan menimbulkan kerugian berupa kekebalan tubuh menurun, lemah, dan terserang penyakit (Naz, el al. 2016). Hasil penelitian ini tidak berbeda dari hasil penelitian yang dilakukan oleh Selfiannisa (2018) pada ayam buras di desa Kramat Kabupaten Bangkalan hasil menunjukkan pada area punggung merupakan area terbanyak untuk pola infestasi kutu Menopon galliane di badingkan area tubuh lainnya. Pola infestasi ini menyebar hampir merata pada ternak jantan dan betina

\section{Preferensi Infestasi Kutu Menopon gallinae Menurut Jenis kelamin}

Hasil rata-rata preferensi infestasi kutu tingkat kesukaaan infestasi menurut jenis kelamin pada ayam kampung disajikan pada Tabel 2. Dari hasil yang ada ayam kampung betina terinfestasi kutu lebih tinggi dari pada ayam kampung jantan.Kutu pada betina dengan rataan 20,35 ekor kutu/ ayam sedangkan pada jantan 14,10 ekor kutu/ ayam.

Tabel 2. Rata-rata Preferensi Infesasi Kutu Menopon gallinae Berdasarkan Jenis Kelamin

\begin{tabular}{lc}
\hline Jenis Kelamin & Rataan (ekor/ ayam ) \\
\hline Jantan & $14,10 \pm 9,69$ \\
Betina & $20,35 \pm 7,65$ \\
\hline Dari hasil pengamatan pada lokasi ayam & sedangkan ayam betina hanya dijadikan \\
kampung jantan dijadikan ayam petarung & ayam bibit, dan terdapat beberapa ayam
\end{tabular}


betina baru selesai mengeram. Salah satu yang menjadi faktor yaitu kebersihan kurangnya perawatan pada ayam betina menjadi salah faktor berkembangnya kutu, hal ini sejalan dengan penelitian yang dilakukan oleh Baktiar et al. (2014) pada burung paruh bengkok di taman marga satwa, burung paruh bengkok yang dilakukan perawatan 2 hari sekali tidak ditemukan kutu dibandingkan dengan burung paruh bengkok yang dilakukan perawatan 1 minggu sekali. Sedangkan untuk penelitian Selfiannisa et al. (2018) menunjukkan hasil yang berbeda pada pada jantan dan betina tidak terdapat perbedaan infestasi kutu. Hal ini disebakan kondisi lingkungan, pola pemeliharaan dan faktor musim pada setiap tempat yang berbeda membuat hasil penelitian menjadi berbeda.

\section{KESIMPULAN}

Berdasarkan hasil dan pembahasan dapat disimpulkan bahwa tidak semua ayam kampung di Desa Tolok terinfestasi kutu. Jenis kutu yang ditemukan hanya Menopon gallinae, dengan prevalensi infestasi kutu 87,5\% dari 40 ekor ayam kampung dan preferensi investasi berdasarkan bagian tubuh menunjukkan pada bagian punggung merupakan daerah tertinggi yang terinfestasi kutu, sedangkan untuk Preferensi infestasi kutu menurut jenis kelamin ternak betina lebih banyak dari ternak jantan.

\section{DAFTAR PUSTAKA}

Armaidi, D. 2016. Epidemiologi penyakit menular dan tidak menular. JMJ. 4(2): 195-202.

Badan pusat Statistik Kabupaten Minahasa 2018.

Baktiar. D. H., R. Susanti, dan M. Rahayuningsih. 2014. Keanekaragaman jenis ektoparasit Burung Paruh Bengko Famili Psittacidae Di Taman Margasatwa Semarang. Unnes Jurnal Life Sci. 3(2).139-147.

Febrananti, D. D. W. 2014. Identifikasi Ektoparasit Pada Ayam Kampung (Gallus Gallus) dan Ayam Arab (Gallus turulus) Di Desa Mulyoagung Kecamatan Dau Kabupaten Malang Seabagai Sumber Belakar Biologi. Skripsi. Universiats Muhammadiah Malang. Malang.

Getu, A. dan M. Birha. 2014. Chicken production systems, performance and associated constraints in North Gondar Zone, Ethiopia. Jurnal Fisheries Livest Prod. 2(2):1-5.

Hadi, U. K., dan S. Soviana. 2013. Pengenalan Ektoparasit, Identifikas, dan pengendaliannya. Institut Pertanian Bogor. Press. Bogor. ISBN. 9789794935668

Hasnah, N. 2017. Identifikasi Ektoparasit Pada Ayam Petelur (Gallus galus) Di Desa Karang Sari, Kecamatan Jati Agung Kabupaten Lampung Selatan. Skripsi. Universitas Lampung. Bandar Lampung. 
Hopla, C.A., L.A. Duren and J.E. Keirans. 1994. Ectoparasites and Classification. Rew. Sci. Tech. Off. Int. Epiz. Journal 13(4): 958-1017.

Husna, S. 2014. Efektivitas Insektisida Terhadap Larva Caplak Sapi (Boophilus microplus) Peternak Sapi Potong Di Jonggol Kabupaten Bogor. Skripsi.Fakultas Kedokteran Hewan, Institut Pertanian Bogor, Bogor Oktober 2014.

Kansil, G. dan H. S. Singh. 2014. Incidence of ectoparasites in bloiler chiken in Meerut. Journal of Argiculture and Veterinary Science 7(1): 55-58.

Lawal, J. R., Z. B. Yusuf, J. Dauda, Y. A. Gazali, A. A. Biu. 2017. Ectoparasites infestasion and its associated risk factrs in village chickens (Gallus gallus domesticus) in and Around Postikum, Yobe State Nigeria. Juornal of Aminalia Husbadry and Dairy Science.Vol. 1. (1).8-9.

Mansjoer, S. S. 1985. Pengkajian Sifatsifat Produksi Ayam Kampung serta Persilangan dengan Ayam Rhode Island. Disertasi. Fakultas Pasca Sarjana. Institut Pertanian Bogor.

Marshall, A.G. 1988. The Geology of Ectoparasite Insect.Academic Press Inc. London .hlm : 30-40.

Naz, S., F. Shaikh dan N. Ali Birmani. 2016. Insidence of chewing Line
(Phthiraptera: Insecta) on Common Mallard, Anas Platyhonchos (Anatidae :Anseriformes : Aves) in Karachi Region, Pakistan. Middle East Journal of Scintific Reseach. 24.(7). 2260-2265

Noble, E.R. dan G. A. Noble. 1989. Parasitologi biologi Parasit hewan. Edisi kelima. UGM. Press. Yogyakarta. 706-714.

Selfiannisa, F., S. Susilowati, P. Hastiutiek, L.T. Suwanti, Kosumo, dan A. Sunarso. 2018. Infestasi ektoparasit kutu pada ayam buras di Desa Kramat Kecamatan bangkalan Kabupaten Bangkalan. Jornal of Parasites Science.Vol. 2. (2): 57-60.

Tamiru, F. A. Dagmawati, G. Askale, S. Salomon, D. Morka and T. Wakole. 2014. Prevalences of Ectoparasites Infestasion in Chiken in Around Ambo Town Ethiopia. Journal of Veterinary Scences Technologi 5(4): 2-5.

Timmreck, T. 2001. Epidermiologi; Journal 164(3): 212-221.

Zein, M.S.A dan A. Saim. 2001. Populasai, pola pertumbuhan ektoparasit Rusa Timor (Cervus timorensis macassaricus Heude 1886) di Padang Savana Taman Nasional Rawa Aopa Watumohai, Provinsi Sulawesi Tenggara. Jurnal Zoologi 6(1): 9-16. 